\title{
Modulation of the acute respiratory effects of winter air pollution by serum and dietary antioxidants: a panel study
}

\author{
L. Grievink*, S.C. van der Zee*, G. Hoek*, H.M. Boezen ${ }^{+}$, P. van't Veer", B. Brunekreef*
}

\begin{abstract}
Modulation of the acute respiratory effects of winter air pollution by serum and dietary antioxidants: a panel study. L. Grievink, S.C. van der Zee, G. Hoek, H.M. Boezen, P. van't Veer, B. Brunekreef. (C) ERS Journals Ltd 1999.

ABSTRACT: This study investigated whether a high dietary intake or serum concentration of antioxidant (pro-) vitamins could attenuate the acute respiratory effects of air pollution in panels of adults $(n=227)$ aged 50-70 yrs with chronic respiratory symptoms in two winters starting in 1993/1994.

Subjects performed daily peak expiratory flow (PEF) measurements in the morning and evening and reported the occurrence of respiratory symptoms in two regions (urban and nonurban) each winter. Logistic regression analysis was used with the prevalences of large PEF decrements as dependent variables and air pollution levels as independent variables. Analyses were performed separately for subjects below and above the median levels of serum $\beta$-carotene and the intake of dietary vitamin $C$ and $\beta$-carotene.

Subjects with low levels of serum $\beta$-carotene more often had large PEF decrements when particles $<10 \mu \mathrm{m}$ in diameter or black smoke levels which were higher compared to subjects with high levels of serum $\beta$-carotene. The same results tended to be observed for dietary vitamin $C$ or $\beta$-carotene, but there were less significant air pollution effects in the low dietary antioxidant group.

The results suggest that serum $\beta$-carotene and to a lesser extent dietary vitamin $C$ and $\beta$-carotene may attenuate peak expiratory flow decrements due to air pollution in subjects with chronic respiratory symptoms.

Eur Respir J 1999; 13: 1439-1446.
\end{abstract}

\begin{abstract}
*Environmental and Occupational Health group, Wageningen Agricultural University, Wageningen, the Netherlands. ${ }^{+}$Dept of Epidemiology and Statistics, University of Groningen, Groningen, the Netherlands. "Division of Human Nutrition and Epidemiology, Wageningen Agricultural University, Wageningen, the Netherlands.

Correspondence: L. Grievink, Environmental and Occupational Health group, Wageningen Agricultural University, P.O. Box 238, $6700 \mathrm{AE}$ Wageningen, the Netherlands. Fax: 31317485278
\end{abstract}

Keywords: Antioxidants diet

peak expiratory flow respiratory symptoms serum

winter air pollution

Received: July 231998

Accepted after revision February 91999

This study was supported by a grant of the Netherlands Asthma Foundation (AFproject 94.26)
The acute effects of air pollution on peak expiratory flow (PEF) and respiratory symptoms have been investigated in several panel studies. Some of these studies were performed on children [1-3] and others on adults with chronic respiratory symptoms [4-6]. The findings of these studies are consistent with an adverse effect of particules with a $50 \%$ cut off aerodynamic diameter $<10 \mu \mathrm{m}$ (PM10) and ozone on lung function and respiratory symptoms.

A possible beneficial effect of antioxidant supplements has been suggested in two small experiments investigating the acute effects of winter air pollution on respiratory health in police officers directing traffic in a city during the winter (the concentrations of air pollutants were unknown) [7]. A single supplement of vitamin $\mathrm{C}$ prevented a decrease in lung function (mean maximal expiratory flow $(\mathrm{MEF} 50))$ and an increase in airway responsiveness to histamine after $2 \mathrm{~h}$ of traffic directing. The other experiment suggested that a vitamin $\mathrm{C}$ supplement for four consecutive days on each morning before work attenuated a decrease in PEF during the workday that was presumably due to air pollution [7]. Modulation of the acute effects of $\mathrm{NO}_{2}$ by supplemental antioxidants was observed in two experimental studies. Three hours of exposure to $7,520 \mu \mathrm{g} \cdot \mathrm{m}^{-3} \mathrm{NO}_{2}$ showed lower levels of lipid peroxidation products in the lung lavage fluid in the group supplemented with vitamins $\mathrm{C}$ and $\mathrm{E}$ [8]. One hour of exposure to $3,760 \mu \mathrm{g} \cdot \mathrm{m}^{-3} \mathrm{NO}_{2}$ showed a reduction of airway responsiveness to methacholine in the group with vitamin C supplements [9]. Most of the evidence of a possible beneficial effect of antioxidants comes, however, from studies investigating ozone in relation to lung function [10-14]. All of these studies evaluated the effect of extra supplemental antioxidants above the normal dietary intake.

Within the framework of a larger panel study on the acute effects of winter air pollution on respiratory health of adults aged 50-70 yrs, this study investigated whether high dietary or serum antioxidant (pro)-vitamins levels could attenuate the acute respiratory effects of winter air pollution.

\section{Materials and methods}

\section{Study design}

The present study was designed within the framework of a large investigation on the relationship between exposure to winter air pollution (three subsequent winters, starting in 1992/1993) and acute respiratory health in selected panels of children and adults with and without chronic respiratory 
symptoms in urban and nonurban control areas in the Netherlands. Data on antioxidant intake and serum levels were collected from all adults in four panels during the last two consecutive winters from November-February starting in 1993/1994. Within the larger investigation, acute effects of winter air pollution were only observed in the panels of adults with chronic respiratory symptoms. Therefore, the present study of modulation by antioxidants is restricted to the panels of adults with chronic respiratory symptoms in the urban and control areas. The urban area in both winters was Amsterdam in the Netherlands with $~ 720,000$ inhabitants. The control areas (Meppel in 1993/1994, Nunspeet in 1994/1995) were small towns with $\sim 25,000-32,000$ inhabitants. The participants performed daily measurements of PEF and completed symptom diaries. Air pollution was monitored daily at fixed sites in each area. At the beginning of the study period, subjects underwent a medical characterization which included measurements of lung function, bronchial responsiveness, allergen skin prick testing and blood sampling for determination of the concentrations of serum total immunoglobulin (Ig)E and the serum antioxidants $\alpha$-tocopherol and $\beta$-carotene. In addition, participants filled out a semiquantitative food frequency questionnaire and a general questionnaire. This general questionnaire provided additional information about chronic respiratory symptoms, medication use, family history of asthma and allergies, occupation, demographic, life-style and environmental factors.

\section{Study population}

The Medical Ethical Committee of the University of Groningen, the Netherlands, approved the study. Subjects were approached by mail and invited to participate in the study. Names and addresses from subjects, aged 50-70 yrs, were obtained by a random sample of the municipal registration. Subjects with chronic respiratory symptoms in each area were selected with a screening questionnaire, which consisted of selected questions of chronic respiratory symptoms (chronic cough, chronic phlegm, productive cough, wheeze with shortness of breath and without having a cold or flu, shortness of breath) from the Dutch part of the European Community Respiratory Health Survey [15]. In the second winter, two exclusion criteria were added: use of $\beta$-blockers (contra-indication for bronchoprovocation test) and work outside of the hometown. Only subjects who signed an informed consent form were included in the study. In the winter of 1993/1994, the planned panel size of subjects with chronic respiratory symptoms was 75 subjects in each of the urban and nonurban control area resulting in a total of 150 subjects. In the winter of 1994/1995, the planned panel size was 60 subjects with chronic respiratory symptoms in each area resulting in a total of 120 subjects for the analysis. A similar size of the panels compared to other panel studies that were able to show an effect of air pollution were chosen $[2,3,16]$.

\section{Methods}

During the study period, peak flow measurements were performed twice a day before breakfast in the morning and before going to bed for three months using Mini-Wright peak flow meters. The participants were instructed to perform these tests before taking medication. Each measurement consisted of three manoeuvres and the readings were reported in a diary.

The diary was also used for reporting the occurrence of acute respiratory symptoms and medication use. Symptoms included in the diary were: cough, phlegm, runny/ stuffed nose, woken up with breathing problems, shortness of breath, wheeze, attacks of shortness of breath with wheeze, fever, eye irritation and sore throat. Subjects had to indicate whether the symptom was absent, slight-tomoderate, or severe. Medication use was assessed by reporting a maximum of three names of the medication and the number of units taken.

Daily measurements of 24-h average concentrations of particules with a $50 \%$ cut-off aerodynamic diameter $<10 \mu \mathrm{m}$ (PM10) and black smoke were measured in both winters in urban and control area from 15:00 h-15:00 h. Detailed methods are published elsewhere [17]. In Amsterdam (urban area), $\mathrm{SO}_{2}$ and $\mathrm{NO}_{2}$ concentrations were obtained in both winters from continuous monitors of the Municipal research agency for the environment and soil mechanics (OMEGAM). For the control areas, the concentrations of $\mathrm{NO}_{2}$ and $\mathrm{SO}_{2}$ were obtained from sites close by the study areas (that is, Barsbeek in the first winter and Witteveen in the second winter) both being part of the National Air Quality Monitoring Network.

The intake of the antioxidant vitamins $\mathrm{C}$ and $\mathrm{E}$, and $\beta$ carotene was measured with a semi-quantitative food frequency questionnaire. The habitual consumption of 178 food items during the last year was calculated from the questionnaire. This questionnaire was developed and validated to quantify, in particular, energy and antioxidant intake $[18,19]$. The structure of this food frequency questionnaire did not allow calculation of the nutrient contribution of vitamin supplements, such as vitamins C, E and $\mathrm{A}$ and multivitamins.

Blood specimens were stored in the refrigerator $\left(4^{\circ} \mathrm{C}\right)$ until centrifugation at the end of the day to obtain serum samples. Aliquots of serum were stored at $-80^{\circ} \mathrm{C}$ until analysis. From each subject, concentrations of $\alpha$-tocopherol and $\beta$-carotene were measured simultaneously by reversephase high performance liquid chromatography (HPLC) in one run at Wageningen Agricultural University, the Netherlands. The method was modified as described by Hess et al. [20]. Duplicate samples $(\mathrm{n}=52)$ were measured to calculate the coefficient of variation of the HPLC measurement for $\beta$-carotene $(10.9 \%)$ and for $\alpha$-tocopherol $(3.0 \%)$.

\section{Analysis}

Subjects were included in the analysis if they had performed PEF measurements and filled out the diary for respiratory symptoms in at least $60 \%$ of the total study period. In addition, the first two days of each subject were excluded from analysis because of a possible learning effect on the PEF measurements [16]. Furthermore, a remaining training effect is removed by allowing nonlinear time trends (see below).

Preliminary individual regression analysis were first performed in two steps to study the effect of person 
characteristics on air pollution response because this was not feasible in the later subgroup analysis. The first step was a linear regression analysis for each individual with the highest PEF in the morning or in the evening as the dependent variable and the air pollutant concentration as the independent variable. Adjustments were made for time trend, influenza incidence and meteorological conditions (see details on confounders below in subgroup analysis). In the second step, the dependent variable was the regression coefficient of the first step and the independent variable was the antioxidant intake or serum concentration. In this step the following person characteristics were evaluated as confounding factors: age, sex, respondents smoking inside the house as a good proxy for smoking status (Pearson $\mathrm{r}=0.77$ in the second winter where both questions were asked), respiratory symptoms (yes/no), elevated total $\operatorname{IgE}$ levels (higher versus lower than the median level of 19.9 $\mathrm{kU} \cdot \mathrm{L}^{-1}$ ).

Before the subgroup analysis, the antioxidant variables were divided into high and low levels with a cut-off point at the median of intake or serum concentration of the antioxidants. Dietary intake of antioxidants was standardized to energy intake before calculating the median [21]. To reduce misclassification of the dietary antioxidant intake, subjects who reported daily use of supplements of vitamins $C(n=9)$ and vitamin $A(n=1)$, and had a dietary intake below the median were classified in the group above the median of antioxidant intake. Subjects who used multivitamins $(n=15)$ and had a dietary intake below the median were also classified in the group above the median of antioxidant intake.

In the subgroup analysis, each of the four panels was divided into subgroups of high and low antioxidant levels. Within these subgroups, the prevalences of respiratory symptoms, bronchodilator use and PEF decrements of $>10 \%$ or $>20 \%$ below the subject-specific median for the morning and evening were calculated; the method for calculation of these prevalences of large PEF decrements has been published in detail previously [22]. Next, the relationships between these prevalences and the different air pollutants were calculated with logistic regression analysis $[16,23]$. The prevalences of the PEF decrements, respiratory symptoms or bronchodilater were used as dependent variables. The following respiratory symptoms were considered: cough, phlegm, lower respiratory symptoms (LRS) and upper respiratory symptoms (URS). LRS were defined as the presence of the following symptoms on a day: wheeze, shortness of breath, and/or attacks of shortness of breath with wheeze; URS: stuffed/runny nose and/or sore throat. Air pollutant concentrations (PM10, black smoke, $\mathrm{NO}_{2}, \mathrm{SO}_{2}$ ) of the same day (lag 0), one day (lag 1), and two days before (lag 2), and a five-day moving average (mean 5) were used separately as independent variables in the logistic regression models. In each model the following adjustments were applied with panelspecific parameter estimates: the minimum temperature, day of the week (weekend or holiday versus weekday), a time trend with the day of the study (number of the day since the start of the study) and a squared and cubic term for the day of the study, mean influenza incidence of the last six days and the mean influenza incidence between day $7-13$ prior to the reporting date. Data on influenza morbidity were obtained from the Netherlands Institute of Primary Health Care (NIVEL). This institute is running a registration network of 46 sentinel general practices (GP) covering $\sim 1 \%$ of the Dutch population. Since the prevalence of PEF decrements, symptoms and medication use was correlated with the prevalence of the previous day, an adjustment for autocorrelation was used in the regression models by specifying a first order autoregressive model for the residuals [23].

Finally, meta-analysis techniques were used to obtain a combined effect estimate for a high versus a low antioxidant intake or serum level from the panel specific effect estimates. Since adjustment for confounders was performed for the panel specific estimates, no additional adjustments were made in the final meta-analysis. A statistical test of the homogeneity of the panel specific effect estimates was conducted using a Chi-squared test. Homogeneity was assumed if the $p$-value was $\geq 0.25$ (conservative cutoff point) and the combined effect estimate was then calculated as a weighted average using the inverse of the variance of the panel specific regression slopes as the weights. In case of heterogeneity $(p<0.25)$ the combined effect estimates were calculated using random effect estimation with the noniterative method with unequal weights [24]. The results are presented as odds ratios (ORs) with $95 \%$ confidence intervals $(\mathrm{CI})$ for an increase in PM10 of $100 \mu \mathrm{g} \cdot \mathrm{m}^{-3}$ and for an increase in black smoke, $\mathrm{SO}_{2}$ and $\mathrm{NO}_{2}$ of $40 \mu \mathrm{g} \cdot \mathrm{m}^{-3}$.

Differences in air pollution effect between high and low levels of antioxidants (intake or serum) were tested with a two-sided Student's t-test.

\section{Results}

In the winter of 1993/1994, 168 subjects with chronic respiratory symptoms started the study. Of these, 46 were excluded from the analysis because 35 subjects did not have at least $60 \%$ of the total PEF measurements, nine subjects did not provide blood samples and two subjects did not complete the food frequency questionnaire. In the winter of 1994/1995, 128 subjects started the study. Of these, 23 were excluded from the analysis because 16 subjects did not have at least $60 \%$ of the total PEF measurements and seven subjects did not provide blood samples. So, a total of 227 subjects were available for analysis.

Table 1 describes relevant population characteristics and the mean intake and serum levels of antioxidants. The mean age of the study population was 60 yrs with an equal number of females and males. Approximately $25 \%$ of the subjects used daily vitamin supplements. The subjects who were excluded from analysis $(n=69)$ did not differ in sex, smoking status, total IgE levels or the use of vitamin supplements but they were slightly older (62 yrs) compared to subjects who were included in the analysis.

Serum and dietary antioxidants did not correlate with age $(\mathrm{r}<0.15)$ and were not different between subjects with a high and low $\operatorname{IgE}$ level or between current and never smokers. Females, however, had higher serum levels of $\beta$ carotene and a higher dietary intake of vitamin $C$ and $\beta$ carotene compared to males (data not shown). Preliminary data analysis using individual linear regression analysis showed that age, sex, smoking and IgE levels did not confound the relationship between antioxidants (serum and dietary) and acute effects of air pollution on PEF (data not shown). In addition, preliminary analysis did not show a 
Table 1. - Characteristics and median intake and serum levels of antioxidants

\begin{tabular}{|c|c|}
\hline Subjects $n$ & 227 \\
\hline Age yrs mean \pm SD & $59.8 \pm 6.3$ \\
\hline Sex $\%$ female & 50.9 \\
\hline Respondents smoking inside the house $\%$ & 27.3 \\
\hline High total $\operatorname{IgE}^{+} \%$ & 18.5 \\
\hline Chronic cough \% & 15.0 \\
\hline Chronic phlegm \% & 20.1 \\
\hline Wheeze with shortness of breath \% & 38.9 \\
\hline Doctor's ever diagnosed asthma \% & 16.0 \\
\hline Asthma attack in past year \% & 4.4 \\
\hline $\mathrm{FEV} 1 / \mathrm{FVC}<70 \% \%$ & 23.6 \\
\hline Vitamin supplement users $\%$ & 25.1 \\
\hline \multicolumn{2}{|l|}{ Dietary intake $\mathrm{mg} \cdot \mathrm{day}^{-1}$ median (range) } \\
\hline Vitamin C & $119.8(34.8-383.7)$ \\
\hline Vitamin E & $13.8(4.0-39.0)$ \\
\hline$\beta$-Carotene & $2.0(0.5-6.1)$ \\
\hline \multicolumn{2}{|c|}{ Serum concentrations $\mathrm{mmol} \cdot \mathrm{L}^{-1}$ median (range) } \\
\hline$\alpha$-Tocopherol & $36.0(3.6-70.6)$ \\
\hline$\beta$-Carotene & $0.30(0.00-2.07)$ \\
\hline
\end{tabular}

FEV1: forced expiratory volume in one second; FVC: forced vital capacity. ${ }^{+}$: high total immunoglobulin (Ig)E was defined as a level $>100 \mathrm{kU} \cdot \mathrm{L}^{-1}$; ${ }^{t}$ : percentage of subjects who used vitamin supplements of vitamins $\mathrm{A}, \mathrm{E}$ and $\mathrm{C}$ and/or multivitamins daily.

modulation of the acute effects of winter air pollution on PEF by serum $\alpha$-tocopherol or dietary vitamin E (data not shown). Therefore, the further results on subgroup analysis will only focus on dietary vitamin $\mathrm{C}$ and $\beta$-carotene and serum $\beta$-carotene. To illustrate the correlation between the different antioxidants used in the different subgroup analysis the Pearson's correlation coefficients were calculated between dietary vitamin $\mathrm{C}$ and dietary $\beta$-carotene $(\mathrm{r}=0.63)$ and between dietary vitamin $\mathrm{C}$ and serum $\beta$-carotene $(\mathrm{r}=$ 0.18 ); the correlation coefficient between $\beta$-carotene in diet and serum was 0.31 .

The air pollution concentrations in urban and nonurban areas were described in detail in another study [17]. Briefly, the mean (range) of PM10 levels in Amsterdam were in the winter of $1993 / 199444 \mu \mathrm{g} \cdot \mathrm{m}^{-3}\left(12-123 \mu \mathrm{g} \cdot \mathrm{m}^{-3}\right)$ and in the winter of $1994 / 199532 \mu \mathrm{g} \cdot \mathrm{m}^{-3}\left(9-90 \mu \mathrm{g} \cdot \mathrm{m}^{-3}\right)$; the concentrations of black smoke were $16 \mu \mathrm{g} \cdot \mathrm{m}^{-3}(0-65$ $\left.\mu \mathrm{g} \cdot \mathrm{m}^{-3}\right)$ in the first winter and $9 \mu \mathrm{g} \cdot \mathrm{m}^{-3}\left(2-28 \mu \mathrm{g} \cdot \mathrm{m}^{-3}\right)$ in the second winter. Mean $\mathrm{NO}_{2}$ in Amsterdam was 47 $\mu \mathrm{g} \cdot \mathrm{m}^{-3}\left(22-76 \mu \mathrm{g} \cdot \mathrm{m}^{-3}\right)$ in the first winter, which was very similar to the second winter. Mean $\mathrm{SO}_{2}$ in Amsterdam was $12 \mu \mathrm{g} \cdot \mathrm{m}^{-3}\left(3-34 \mu \mathrm{g} \cdot \mathrm{m}^{-3}\right)$ in the first winter and 7 $\mu \mathrm{g} \cdot \mathrm{m}^{-3}\left(1-24 \mu \mathrm{g} \cdot \mathrm{m}^{-3}\right)$ in the second winter.

Table 2 shows the associations between PM10 (increase of $100 \mu \mathrm{g} \cdot \mathrm{m}^{-3}$ ) and the prevalence of PEF decrements $>10 \%$ or $20 \%$ in the morning and evening for subjects with high and low levels of serum $\beta$-carotene. The prevalences of PEF decrements of $>20 \%$ were in most panels $<2 \%$ and the CIs of the ORs of these large PEF decrements were very wide. Subjects with a low level of serum $\beta$-carotene had ORs mostly above one, in particular, for the morning PEF decrements. Subjects with a high level of serum $\beta$-carotene, however, had ORs which were mostly not different from one. The effect of PM10 was significantly different for most of the $20 \%$ PEF decrements in the morning between high and low serum $\beta$-carotene levels.

Table 3 shows that the effect of PM10 of the previous day on URS and LRS or medication use was not different between subjects with high and low levels of serum $\beta$ carotene. The results were similar for different lags of PM10. The effect of black smoke (increase of $40 \mu \mathrm{g} \cdot \mathrm{m}^{-3}$ ) of the previous day on URS and LRS or medication use was not different between subjects with high and low levels of serum $\beta$-carotene (table 3 ). The results were similar for different lags of black smoke. In addition, the effect of black smoke and PM10 on cough and phlegm was not different for a high versus a low serum $\beta$-carotene concentration (data not shown).

Table 4 shows the associations between black smoke and the prevalence of PEF decrements $>10 \%$ or $20 \%$ in the morning and evening for the groups with a high and low level of serum $\beta$-carotene. Subjects with a low level of serum $\beta$-carotene had ORs mostly above one, in particular, for a black smoke concentration of the same day, the previous day or a 5-day mean. Subjects with a high

Table 2. - Association ${ }^{+}$between the prevalence of peak expiratory flow (PEF) decrements of 10 and $20 \%$ and particles with a $50 \%$ cut-off aerodynamic diameter of $<10 \mu \mathrm{m}$ (PM10) for high $(n=113)$ and low $(n=114)$ serum $\beta$-carotene concentration

\begin{tabular}{|c|c|c|c|c|c|c|c|c|}
\hline & \multicolumn{4}{|c|}{ Low serum $\beta$-carotene $<0.30 \mu \mathrm{mol} \cdot \mathrm{L}^{-1}$} & \multicolumn{4}{|c|}{ High serum $\beta$-carotene $\geq 0.30 \mu \mathrm{mol} \cdot \mathrm{L}^{-1}$} \\
\hline & \multicolumn{4}{|c|}{ PEF decrements } & \multicolumn{4}{|c|}{ PEF decrements } \\
\hline & \multicolumn{2}{|c|}{ Morning } & \multicolumn{2}{|c|}{ Evening } & \multicolumn{2}{|c|}{ Morning } & \multicolumn{2}{|c|}{ Evening } \\
\hline & $10 \%$ & $20 \%$ & $10 \%$ & $20 \%$ & $10 \%$ & $20 \%$ & $10 \%$ & $20 \%$ \\
\hline \multirow{2}{*}{$\begin{array}{l}\text { Range PEF } \\
\text { prevalences } \\
\text { Lag } 0\end{array}$} & & & & & & & & \\
\hline & $\begin{array}{c}J .4-0.2 \\
1.41 \\
(0.91-2.20)\end{array}$ & $\begin{array}{c}3.06^{*} \\
(1.34-7.95)\end{array}$ & $\begin{array}{c}4.0-0.4 \\
1.14 \\
(0.75-1.75)\end{array}$ & $\begin{array}{c}2.56 \\
(1.01-6.48)\end{array}$ & $\begin{array}{c}0.1-0.3 \\
0.91 \\
(0.57-1.46)\end{array}$ & $\begin{array}{c}0.0-2.2 \\
(0.40-2.10)\end{array}$ & $\begin{array}{c}1.09 \\
(0.66-1.78)\end{array}$ & $\begin{array}{c}0.50 \\
0.20 \\
(0.01-4.58)\end{array}$ \\
\hline Lag 1 & $\begin{array}{c}1.62 \\
(1.10-2.40)\end{array}$ & $\begin{array}{c}3.43^{*} \\
(1.35-8.71)\end{array}$ & $\begin{array}{c}1.06 \\
(0.71-1.58)\end{array}$ & $\begin{array}{c}1.81 \\
(0.10-32)\end{array}$ & $\begin{array}{c}0.98 \\
(0.63-1.52)\end{array}$ & $\begin{array}{c}0.54 \\
(0.25-1.21)\end{array}$ & $\begin{array}{c}0.91 \\
(0.25-3.31)\end{array}$ & $\begin{array}{c}2.93 \\
(0.57-15)\end{array}$ \\
\hline Lag 2 & $\begin{array}{c}1.16 \\
(0.77-1.77)\end{array}$ & $\begin{array}{c}0.86 \\
(0.18-4.10)\end{array}$ & $\begin{array}{c}0.95 \\
(0.60-1.49)\end{array}$ & $\begin{array}{c}6.25 \\
(0.0-45602)\end{array}$ & $\begin{array}{c}0.80 \\
(0.53-1.19)\end{array}$ & $\begin{array}{c}0.63 \\
(0.14-2.78)\end{array}$ & $\begin{array}{c}0.62 \\
(0.24-1.59)\end{array}$ & $\begin{array}{c}0.55 \\
(0.19-1.66)\end{array}$ \\
\hline Mean 5 & $\begin{array}{c}2.19^{*} \\
(1.14-4.19)\end{array}$ & $\begin{array}{c}3.30 * \\
(0.40-27.2)\end{array}$ & $\begin{array}{c}0.90 \\
(0.50-1.61)\end{array}$ & $\begin{array}{c}1.93 \\
(0.27-13.9)\end{array}$ & $\begin{array}{c}0.75 \\
(0.36-1.57)\end{array}$ & $\begin{array}{c}0.14 \\
(0.03-0.67)\end{array}$ & $\begin{array}{c}0.49 \\
(0.06-4.04)\end{array}$ & $\begin{array}{c}0.77 \\
(0.03-23)\end{array}$ \\
\hline
\end{tabular}

${ }^{+}$: presented as odds ratios (95\% confidence intervals) for an increase in PM10 of $100 \mu \mathrm{g} \cdot \mathrm{m}^{-3} ; *$ : $\mathrm{p}<0.05$, the effect of air pollution was different between a high and low serum level of $\beta$-carotene (two-sided Student's t-test). ${ }^{*}$ : range in the mean PEF prevalences of each panel. 
Table 3. - Association ${ }^{+}$between the prevalence of respiratory symptoms or medication use and air pollution of the previous day for a high $(n=113)$ and a low $(n=114)$ serum $\beta$-carotene concentration

\begin{tabular}{|c|c|c|c|c|c|c|}
\hline & \multicolumn{3}{|c|}{ Low serum $\beta$-carotene $<0.30 \mu \mathrm{mol} \cdot \mathrm{L}^{-1}$} & \multicolumn{3}{|c|}{ High serum $\beta$-carotene $\geq 0.30 \mu \mathrm{mol} \cdot \mathrm{L}^{-1}$} \\
\hline & LRS & URS & Medication use & LRS & URS & Medication use \\
\hline Prevalences ${ }^{\dagger}$ & $16.2-34.8$ & $25.5-36.8$ & $4.5-18.4$ & $15.3-20.2$ & $19.3-42.0$ & $7.1-16.6$ \\
\hline PM10 & 1.04 & 1.10 & 1.01 & 1.07 & 1.13 & 1.03 \\
\hline & $(0.92-1.18)$ & $(0.95-1.27)$ & $(0.86-1.18)$ & $(0.91-1.26)$ & $(0.97-1.31)$ & $(0.92-1.16)$ \\
\hline Black smoke & $\begin{array}{c}1.10 \\
(0.97-1.25)\end{array}$ & $\begin{array}{c}1.17 \\
(1.02-1.34)\end{array}$ & $\begin{array}{c}0.98 \\
(0.78-1.24)\end{array}$ & $\begin{array}{c}0.93 \\
(0.71-1.22)\end{array}$ & $\begin{array}{c}1.16 \\
(1.01-1.33)\end{array}$ & $\begin{array}{c}1.06 \\
(0.94-1.19)\end{array}$ \\
\hline
\end{tabular}

${ }^{+}$: presented as an odds ratios $(95 \%$ confidence intervals) for an increase in particles with a $50 \%$ cut-off aerodynamic diameter of $<10$ $\mu \mathrm{m}$ of $100 \mu \mathrm{g} \cdot \mathrm{m}^{-3}$ and in black smoke of $40 \mu \mathrm{g} \cdot \mathrm{m}^{-3} ;{ }^{*}$ range in mean prevalences of each panel for upper respiratory symptoms (URS), lower respiratory symptoms (LRS) and medication use.

level of serum $\beta$-carotene had ORs that mostly did not differ from zero. The effect of black smoke was statistically different for most of the $20 \%$ PEF decrements in the morning and evening between high and low serum $\beta$ carotene levels.

The effect of $\mathrm{NO}_{2}$ and $\mathrm{SO}_{2}$ on large PEF decrements was slightly higher in the group with low serum $\beta$-carotene levels compared to the group of subjects with high serum $\beta$-carotene levels (data not shown).

Table 5 shows that the ORs of black smoke on $10 \%$ PEF decrements were mostly above one for the group with a low dietary intake of vitamin $C$ or $\beta$-carotene, while the ORs in the group with a high intake of these antioxidants were not. Although there was only one significant effect of 5-day moving average of black smoke on the morning PEF decrement in the low dietary $\beta$-carotene group, there were more significant differences between air pollution effect estimates in the high and low intake of vitamin $\mathrm{C}$ and $\beta$-carotene groups. Similar results were observed for $20 \%$ PEF decrements in relation to black smoke and for PM10, although the ORs of PM10 on PEF decrements were slightly lower in subjects with low dietary antioxidants (data not shown).

The associations among PM10, black smoke, $\mathrm{NO}_{2}, \mathrm{SO}_{2}$, $10 \%$ PEF decrements in the morning and evening, LRS and URS were not different for subjects with a low versus a high intake of vitamin $\mathrm{C}$ or $\beta$-carotene (data not shown).

\section{Discussion}

This study suggests that subjects with chronic respiratory symptoms and with low serum $\beta$-carotene levels were more affected by air pollution than those with high serum $\beta$-carotene levels. This effect was most pronounced for the effect of particulate matter (PM10 or black smoke) on the prevalence of large PEF decrements. There were also some differences in particulate matter effects between groups with high and low intake of vitamin $C$ and $\beta$-carotene, although the effect itself of particulate matter was only borderline statistically significant in the low dietary antioxidant group.

To the authors' knowledge, there has only been one other study investigating a possible modulation of the acute effect of winter air pollution on PEF but this study focused on vitamin $\mathrm{C}$ supplements [7]. In this crossover study, subjects were police officers $(n=20)$ directing traffic for four consecutive days receiving a vitamin $\mathrm{C}$ supplement $(2 \mathrm{~g})$ or placebo on each morning before work. Peak flow was measured at the beginning and at the end of the working day. The results suggest that the PEF decreased during the working day in the control group but not in the vitamin group. It should be noted that the levels of air pollution were unknown and that the dose of supplemental vitamin $\mathrm{C}$ could not be compared to the levels of dietary intake because it was 14-times the mean

Table 4. - Association ${ }^{+}$between the prevalence of peak expiratory flow (PEF) decrements of 10 and $20 \%$ and black smoke for high $(n=113)$ and low $(n=114)$ serum $\beta$-carotene concentration

\begin{tabular}{|c|c|c|c|c|c|c|c|c|}
\hline & \multicolumn{4}{|c|}{ Low serum $\beta$-carotene $<0.30 \mu \mathrm{mol} \cdot \mathrm{L}^{-1}$} & \multicolumn{4}{|c|}{ High serum $\beta$-carotene $\geq 0.30 \mu \mathrm{mol} \cdot \mathrm{L}^{-1}$} \\
\hline & \multicolumn{4}{|c|}{ PEF decrements } & \multicolumn{4}{|c|}{ PEF decrements } \\
\hline & \multicolumn{2}{|c|}{ Morning } & \multicolumn{2}{|c|}{ Evening } & \multicolumn{2}{|c|}{ Morning } & \multicolumn{2}{|c|}{ Evening } \\
\hline & $10 \%$ & $20 \%$ & $10 \%$ & $20 \%$ & $10 \%$ & $20 \%$ & $10 \%$ & $20 \%$ \\
\hline $\begin{array}{l}\text { Range PEF } \\
\text { prevalences }\end{array}$ & $5.4-6.2$ & $0.6-2.5$ & $4.6-6.4$ & $0.3-1.7$ & $5.1-8.3$ & $0.6-2.2$ & $3.0-7.6$ & $0.3-2.2$ \\
\hline Lag 0 & $\begin{array}{c}1.80 \\
(1.14-2.82)\end{array}$ & $\begin{array}{c}5.69^{*} \\
(2.49-13.0)\end{array}$ & $\begin{array}{c}1.04 \\
(0.70-1.56)\end{array}$ & $\begin{array}{c}3.92 * \\
(1.67-9.20)\end{array}$ & $\begin{array}{c}1.09 \\
(0.72-1.66)\end{array}$ & $\begin{array}{c}1.01 \\
(0.52-1.97)\end{array}$ & $\begin{array}{c}0.90 \\
(0.48-1.72)\end{array}$ & $\begin{array}{c}0.76 \\
(0.28-2.04)\end{array}$ \\
\hline Lag 1 & $\begin{array}{c}1.67^{*} \\
(1.15-2.43)\end{array}$ & $\begin{array}{c}2.72^{*} \\
(1.36-5.45)\end{array}$ & $\begin{array}{c}1.55 \\
(0.71-3.38)\end{array}$ & $\begin{array}{c}1.63^{*} \\
(0.0-1084)\end{array}$ & $\begin{array}{c}1.00 \\
(0.69-1.43)\end{array}$ & $\begin{array}{c}0.37 \\
(0.09-1.47)\end{array}$ & $\begin{array}{c}0.83 \\
(0.48-1.45)\end{array}$ & $\begin{array}{c}0.0 \\
\left(0.0-5 \times 10^{6}\right)\end{array}$ \\
\hline Lag 2 & $\begin{array}{c}1.14 \\
(0.78-1.65)\end{array}$ & $\begin{array}{c}0.68 \\
(0.03-17.3)\end{array}$ & $\begin{array}{c}0.86 \\
(0.63-1.19)\end{array}$ & $\begin{array}{c}0.18 \\
(0.07-0.47)\end{array}$ & $\begin{array}{c}0.88 \\
(0.62-1.23)\end{array}$ & $\begin{array}{c}0.22 \\
(0.02-3.04)\end{array}$ & $\begin{array}{c}0.86 \\
(0.36-2.08)\end{array}$ & $\begin{array}{c}0.09 \\
(0.00-14.1)\end{array}$ \\
\hline Mean 5 & $\begin{array}{c}3.90^{*} \\
(2.07-7.36)\end{array}$ & $\begin{array}{c}31.5^{*} \\
(0.23-4214)\end{array}$ & $\begin{array}{c}1.05 \\
(0.62-1.76)\end{array}$ & $\begin{array}{c}35.1^{*} \\
(5.96-206)\end{array}$ & $\begin{array}{c}0.76 \\
(0.32-1.81)\end{array}$ & $\begin{array}{c}0.76 \\
(0.25-2.35)\end{array}$ & $\begin{array}{c}0.30 \\
(0.04-2.25)\end{array}$ & $\begin{array}{c}0.12 \\
(0.02-0.79)\end{array}$ \\
\hline
\end{tabular}

${ }^{+}:$presented as odds ratios $\left(95 \%\right.$ confidence intervals) for an increase in black smoke of $40 \mu \mathrm{g} \cdot \mathrm{m}^{-3}$; ${ }^{\star}$ : range in the mean PEF prevalences of each panel. *: $\mathrm{p}<0.05$, the effect of air pollution was different between a high and low serum level of $\beta$-carotene (twosided Student's t-test). 
Table 5. - Association ${ }^{+}$between the prevalence of $10 \%$ expiratory flow (PEF) decrements and black smoke pollution levels for high and low dietary antioxidant intake

\begin{tabular}{|c|c|c|c|c|}
\hline Air pollution & $\begin{array}{l}\text { Low dietary vitamin } \mathrm{C} \\
\qquad(\mathrm{n}=92)\end{array}$ & $\begin{array}{l}\text { High dietary vitamin } C \\
\qquad(\mathrm{n}=135)\end{array}$ & $\begin{array}{l}\text { Low dietary } \beta \text {-carotene } \\
\qquad(\mathrm{n}=97)\end{array}$ & $\begin{array}{l}\text { High dietary } \beta \text {-carotene } \\
\qquad(\mathrm{n}=130)\end{array}$ \\
\hline \multicolumn{5}{|l|}{ Lag 0} \\
\hline Morning PEF & $1.21(0.82-1.78)$ & $1.28(0.87-1.88)$ & $1.31(0.85-2.02)$ & $0.92(0.49-1.72)$ \\
\hline Evening PEF & $1.23(0.81-1.89)^{*}$ & $0.69(0.42-1.13)$ & $0.96(0.61-1.52)$ & $1.05(0.68-1.63)$ \\
\hline \multicolumn{5}{|l|}{ Lag 1} \\
\hline Morning PEF & $1.28(0.93-1.76)$ & $0.96(0.56-1.65)$ & $1.25(0.86-1.80)$ & $0.90(0.47-1.69)$ \\
\hline Evening PEF & $1.30(0.91-1.85)$ & $0.85(0.55-1.31)$ & $1.04(0.71-1.52)$ & $0.81(0.41-1.58)$ \\
\hline \multicolumn{5}{|l|}{ Lag 2} \\
\hline Morning PEF & $1.24(0.76-2.02)$ & $0.87(0.63-1.21)$ & $1.48(0.83-2.64)^{*}$ & $0.71(0.51-1.00)$ \\
\hline Evening PEF & $1.35(0.89-2.05)^{*}$ & $0.58(0.37-0.89)$ & $1.40(0.99-1.97)^{*}$ & $0.49(0.19-1.21)$ \\
\hline \multicolumn{5}{|l|}{ Mean 5} \\
\hline Morning PEF & $1.52(0.94-2.46)$ & $0.98(0.34-2.82)$ & $2.11(1.09-4.09)^{*}$ & $0.59(0.17-2.05)$ \\
\hline Evening PEF & $1.41(0.79-2.53)^{*}$ & $0.47(0.23-0.94)$ & $1.46(0.74-2.88)^{*}$ & $0.31(0.07-1.48)$ \\
\hline
\end{tabular}

: presented as odds ratios $\left(95 \%\right.$ confidence intervals) for an increase in black smoke of $40 \mu \mathrm{g} \cdot \mathrm{m}^{-3} .{ }^{*} \mathrm{p}<0.05$, the effect of air pollution was different between a high and low dietary intake of antioxidants (two-sided Student's t-test).

intake and 4- times the maximum intake of vitamin $\mathrm{C}$ in the present study. So the present study was the first study investigating dietary intake and serum levels of antioxidants in relation to the acute effects of winter air pollution.

Most other intervention studies under ambient conditions were investigating a possible modulation of the acute effect of ozone by antioxidant supplements. Two intervention studies were carried out among cyclists performing lung function measurements before and after exercise in the Netherlands. In the first study in the summer of 1994 , twelve subjects were supplemented with a daily cocktail of vitamin C (650 mg), vitamin E (75 mg), and $\beta$-carotene (15 $\mathrm{mg})$ for 10 weeks. The control group $(\mathrm{n}=14)$ did not receive a plabebo. An acute effect of ozone (8-h mean 101 $\mu \mathrm{g} \cdot \mathrm{m}^{-3}$ ) was observed in the control group but not in the vitamin group [13]. The second study in the summer of 1996 was placebo-controlled. Half of the 38 cyclists received daily $100 \mathrm{mg}$ vitamin $\mathrm{E}$ and $500 \mathrm{mg}$ vitamin $\mathrm{C}$ for 15 weeks. Lung function (forced expiratory volume in one second (FEV1) and forced vital capacity (FVC)) was negatively associated with ozone concentration (8-h mean $77 \mu \mathrm{g} \cdot \mathrm{m}^{-3}$ ) in the placebo group but not in the vitamin group [14]. Street workers $(n=49)$ in Mexico-city received the same cocktail as the cyclists of 1994 in the Netherlands in a placebo-controlled crossover study [12]. Although the street workers were not exercising heavily, the mean $1 \mathrm{~h}$ maximum ozone concentration was higher (110 parts per billion (ppb), equivalent to $163 \mu \mathrm{g} \cdot \mathrm{m}^{-3}$ for conditions in Mexico City). The results of this study suggest that, in particular, in the first phase of the study the placebo group had a significant effect of ozone on FEV1, FVC and maximal mid-expiratory flow (MMEF) while the supplementation group did not show an ozone effect. Since all these studies under ambient conditions supplemented their subjects $(\sim 4$ - times the mean intake of vitamin $C$ and $\sim 7$-times the mean intake of vitamin $E$ and $\beta$-carotene), the question remains if the possible beneficial effect of antioxidants could be reached by a higher dietary intake alone.

Selection bias in the relation between air pollution and PEF is not very likely because in a panel study each subject is their own control in the exposure of air pollution. However, some selection could have occurred, since, more health conscious subjects were participating in the present study. This was evident because of the relatively high percentage of daily supplement users $(25 \%)$. In a random sample of Dutch adults aged 20-59 yrs measured in 1994 and 1995, the percentage of daily supplement use (measured with the same questionnaire) was $<10 \%$ [25]. Although the present study population was slightly older (50-70 yrs), the number of supplement users in these older subjects was not different in the Dutch national food consumption Survey in 1987-1988 compared to other adult age groups [26]. If subjects would take supplements because of experienced adverse health effects of air pollution, a bias towards a clear positive relationship between antioxidants and acute respiratory effect of air pollution could occur. Since the present findings did not indicate clear positive associations of dietary antioxidants and excluding supplement users in the preliminary analysis did not change the results, the use of supplements was probably not associated with the experienced acute effects of air pollution. This is supported by the observation that the antioxidant groups differ in air pollution effects on PEF and not on respiratory symptoms.

The relative validity of the antioxidants in the present food frequency questionnaire (FFQ) was determined in a validation study [19]. In this study, the mean of the antioxidants from four different blood samples and from 12 repeated 24-h recalls were calculated. The Pearson correlation coefficient between $\beta$-carotene from the FFQ and serum levels was negative for males and 0.13 for females; the correlation coefficients between the FFQ and $24-\mathrm{h}$ recalls for $\beta$-carotene was higher but still poor $(\mathrm{r}=0.34$ for males, $\mathrm{r}=0.47$ for females). These correlation coefficients are low compared to other validation studies $[27,28]$. Some factors might explain these lower correlation coefficients, such as a poor relative validity of the vegetable intake from the FFQ, heterogeneity of some food items with respect to $\beta$-carotene composition, and the low bioavailibility of the major sources of $\beta$-carotene in the Netherlands [19]. These low correlation coefficients suggest that the FFQ was limited with respect to measuring the intake of $\beta$-carotene that could have contributed to misclassification and might explain why the modifying effect of dietary antioxidants on air pollution effects was less than for serum $\beta$-carotene. 
Another form of misclassification of the dietary antioxidants (vitamin $\mathrm{C}$ and $\beta$-carotene) might have occurred due to a relatively high percentage of subjects $(25 \%)$ using daily vitamin supplements. The nutrient contribution of these supplements could not be added to the intake of dietary antioxidants due to the structure of the FFQ. To reduce the misclassification, subjects with a daily use of vitamin supplements $(11 \%)$ were classified in the group of subjects with an intake above the median. However, a possible remaining misclassification would have biased a modifying effect of dietary antioxidants towards the null. This might also explain why the modifying effect of dietary antioxidants on air pollution effects was less than that for serum $\beta$-carotene.

Whether acute effects of air pollution are modulated by antioxidants can only be detected if the range in exposure to antioxidants is sufficiently large in the population under study. In the present study population, the range in dietary antioxidants was $<2$ between the 25 th to 75 th percentile. Dietary vitamin $\mathrm{C}$ had a range of $88-169 \mathrm{mg}$ and dietary $\beta$-carotene had a range of $1.52-2.69 \mathrm{mg}$. These dietary ranges were relatively small compared to the range in serum $\beta$-carotene which was $\sim 2.5$ between the 25 th $(0.20$ $\left.\mu \mathrm{mol} \cdot \mathrm{L}^{-1}\right)$ and 75 th percentile $\left(0.48 \mu \mathrm{mol} \cdot \mathrm{L}^{-1}\right)$ of serum $\beta$ carotene. So, a more clear effect of dietary antioxidants might have occurred if the range in dietary antioxidants had been larger in this study population.

Furthermore, the modifying effect of dietary antioxidants might only be detected if there was a substantial part of the population with a low dietary intake of the antioxidants. The mean intake of vitamin $C\left(135 \mathrm{mg}^{- \text {day }^{-1}}\right)$ and $\beta$-carotene $\left(2.2 \mathrm{mg} \cdot \mathrm{day}^{-1}\right)$ was, in this study, not different compared to a study in a random sample of the Dutch population using the same FFQ [25]. Although the mean intake of these antioxidants was comparable to another Dutch population, intake below the median $(<120$ $\mathrm{mg} \cdot$ day $^{-1}$ ) might still be too high to see a clear difference in respiratory effect of air pollution.

Serum levels of $\beta$-carotene could be a better marker for antioxidant exposure in the lung tissue than the intake of $\beta$ carotene. This was confirmed in a small $(n=21)$ study in which $\beta$-carotene was measured in lung tissues, serum and in diet with a FFQ [29]. The questionnaire was designed to measure both dietary and supplemental $\beta$-carotene. The Pearson's correlation coefficient between serum concentration of $\beta$-carotene and lung tissue $(r=0.72)$ was higher than the correlation between dietary intake of $\beta$-carotene and the lung tissue level $(\mathrm{r}=0.54)$. Therefore, a clearer modifying effect on air pollution effects of serum $\beta$ carotene compared to dietary $\beta$-carotene is also more reasonable to expect from a metabolic point of view.

The postulated mechanism for lung function decrements after ozone exposure is a reduction of maximal inspiratory capacity through stimulation of the neural receptors in the upper airways. Cyclo-oxygenase products of arachidonic acid stimulate these receptors which are released on exposure to ozone [30, 31]. Vitamins $\mathrm{C}$ and $\mathrm{E}$ have been shown to affect this arachidonic acid metabolism, but the role of antioxidants in this mechanism is not fully understood $[32,33]$. Another hypothesized mechanism of the acute effects of air pollution would be an increase in inflammatory mediators shown in the bronchoalveolar lavage within $1 \mathrm{~h}[34,35], 6 \mathrm{~h}[36], 18 \mathrm{~h}[34,35]$, and 24 $\mathrm{h}[36]$ after ozone exposure. Antioxidants could modulate the airway response to air pollution by reducing the influx of inflammatory cells [37]. Which of the two postulated mechanisms is relevant to the observed modulation in the present study remains unclear because inflammatory markers were not measured. To the authors' knowledge, the mechanistic action of a possible protective role of $\beta$-carotene in relation to acute respiratory effects of air pollution has not been investigated.

The statistical significance and number of positive associations were similar for PM10 and black smoke in the group with low and high levels of dietary or serum antioxidants. ORs for black smoke tended to be higher, although the CIs overlapped with those for PM10. Stronger black smoke effects might be due to the fact that black smoke is an indicator of fine (carbonaseous) particles whereas PM10 also includes coarse particles [38].

In conclusion, the results of the present study suggest that serum $\beta$-carotene attenuated the respiratory effects of air pollution, in particular, the prevalence of large peak expiratory flow decrements in relation to particles with a $50 \%$ cut-off aerodynamic diameter $<10 \mu \mathrm{m}$ and black smoke in a panel of subjects with chronic respiratory symptoms. A difference in effects of particles with a $50 \%$ cut-off aerodynamic diameter $<10 \mu \mathrm{m}$ and black smoke on large peak expiratory flow decrements tended to be present between groups with high and low dietary vitamin $\mathrm{C}$ and $\beta$-carotene.

Acknowledgements. The authors thank J. Gigler, S. Halfwerk, K. Idema, F. Penning-van Beest and W. Wamelink for assistance in collecting the food frequency questionnaire data; and K. Hartog and P. Versloot for the analysis of the serum antioxidants.

\section{References}

1. Pope CA III, Dockery DW. Acute health effects of PM10 pollution on symptomatic and asymptomatic children. $\mathrm{Am}$ Rev Respir Dis 1992; 145: 1123-1128.

2. Roemer W, Hoek G, Brunekreef B. Effect of ambient winter air pollution on respiratory health of children with chronic respiratory symptoms. Am Rev Respir Dis 1993; 147: 118-124.

3. Timonen KL, Pekkanen J. Air pollution and respiratory health among children with asthmatic or cough symptoms. Am J Respir Crit Care Med 1997; 156: 546-552.

4. Pope CA III, Kanner RE. Acute effects of PM10 pollution on pulmonary function of smokers with mild to moderate chronic obstructive pulmonary disease. Am Rev Respir Dis 1993; 147: 1336-1340.

5. Pope CA III, Dockery DW, Spengler JD, Raizenne ME. Respiratory health and PM10 pollution. Am Rev Respir Dis 1991; 144: 668-674.

6. Dusseldorp A, Kruize H, Brunekreef B, Hofschreuder P, de Meer G, van Oudvorst AB. Associations of PM10 and airborne iron with respiratory health of adults living near a steel factory. Am J Respir Crit Care Med 1995; 152: 1932-1939.

7. Bucca C, Rolla G, Farina JC. Effect of vitamin C on transient increase of bronchial responsiveness in conditions affecting the airways. Ann NY Acad Sci 1992; 669: 175-187.

8. Mohsenin V. Lipid peroxidation and antielastase activity in the lung under oxidant stress: role of antioxidant defenses. J Appl Physiol 1991; 70: 1456-1462. 
9. Mohsenin V. Effect of vitamin $\mathrm{C}$ on $\mathrm{NO}_{2}$-induced airway hyperresponsiveness in normal subjects. Am Rev Respir Dis 1987; 136: 1408-1411.

10. Chatham MD, Eppler JH Jr, Saunder LR, Green D, Kulle TJ. Evaluation of the effects of vitamin $\mathrm{C}$ on ozone induced bronchoconstriction in normal subjects. Ann NY Acad Sci 1987; 498: 269-279.

11. Trenga CA, Williams PV, Koenig JQ. Dietary antioxidants attenuate ozone-induced bronchial hyperresponsiveness (BHR) in asthmatic adults. Am J Respir Crit Care Med 1997; 155: A732.

12. Romieu I, Meneses F, Ramirez M, et al. Antioxidant supplementation and respiratory functions among workers exposed to high levels of ozone. Am J Respir Crit Care Med 1998; 158: 226-232.

13. Grievink L, Jansen SMA, van't Veer P, Brunekreef B. Acute effects of ozone on pulmonary function of cyclists receiving antioxidant supplements. Occup Environ Med 1998; 55: 13-17.

14. Grievink L, Zijlstra AG, Xiaodong K, Brunekreef B. Double-blind intervention trial on modulation of ozone effects on pulmonary function by antioxidant supplements. Am J Epidemiol 1999; 149: 306-314.

15. Burney PGJ, Luczynska Q, Chinn S, Jarvis D. The European Community respiratory health survey. Eur Respir J 1994; 7: 954-960.

16. Roemer W, Hoek G, Brunekreef B, et al. Effect of short-term changes in urban air pollution on the respiratory health of children with chronic respiratory symptoms: the PEACE project: introduction. Eur Respir Rev 1998; 8: 4-11.

17. van der Zee S, Hoek G, Harssema H, Brunekreef B. Characterization of particulate air pollution in urban and non-urban areas in the Netherlands. Atmos Environ 1998; In Press.

18. Ocké MC, Bueno de Mesquita HB, Goddijn HE, et al. The Dutch EPIC food frequency questionnaire I. Description of the questionnaire, and relative validity and reproducibility for food groups. Int J Epidemiol 1997; 26: S37-S48.

19. Ocké MC, Bueno de Mesquita HB, Pols MA, Smit HA, van Staveren WA, Kromhout D. The Dutch EPIC food frequency questionnaire II. Relative validity and reproducibility for nutrients. Int J Epidemiol 1997; 26: S49S58.

20. Hess D, Keller HE, Oberlin B, Bonfanti R, Schüep W. Simultaneous determination of retinol, tocopherols, carotenes and lycopene in plasma by means of high-performance liquid chromatography on reversed phase. Int $J$ Vitam Nutr Res 1991; 61: 232-238.

21. Willett WC, Stampfer MJ. Total energy intake: implications for epidemiologic analyses. Am J Epidemiol 1986; 124: $17-27$.

22. Hoek G, Dockery DW, Pope CA III, Neas L, Roemer W, Brunekreef B. Associations between PM10 and decrements in peak expiratory flow rates in children: reanalysis of data from five panel studies. Eur Respir J 1998; 11: $1307-1311$.
23. SAS Institute. SAS/ETS User's Guide. 2nd Edn. Cary, NC SAS Institute Inc., 1993.

24. DerSimonian R, Laird N. Meta-analysis in clinical trials. Controlled Clin Trials 1986; 7: 177-188.

25. Grievink L, Smit HA, Ocké MC, van't Veer P, Kromhout D. Dietary intake of antioxidant (pro-)vitamins, respiratory symptoms and pulmonary function: the MORGENstudy. Thorax 1998; 53: 166-171.

26. Dorant E, van den Brandt PA, Hamstra AM, et al. The use of vitamins, minerals, and other dietary supplements in the Netherlands. Int J Vitam Nutr Res 1993; 63: 4-10.

27. Coates RJ, Eley JW, Block G, et al. An evaluation of a food frequency questionnaire for assessing dietary intake of specific carotenoids and vitamin $\mathrm{E}$ among low-income black women. Am J Epidemiol 1991; 134: 658-671.

28. Stryker WS, Kaplan LA, Stein EA, Stampfer MJ, Sober A, Willett WC. The relation of diet, cigarette smoking, and alcohol consumption to plasma beta-carotene and alpha-tocopherol levels. Am J Epidemiol 1988; 127: 283296.

29. Redlich CA, Grauer JN, van Bennekum AM, Clever SL, Ponn RB, Blaner WS. Characterization of carotenoid, vitamin $\mathrm{A}$, and $\alpha$-tocopherol levels in human lung tissue and pulmonary macrophages. Am J Respir Crit Care Med 1996; 154: 1436-1443.

30. Hazucha MJ, Bates DV, Bromberg PA. Mechanism of action of ozone on the human lung. J Appl Physiol 1989; 67: 1535-1541.

31. Hazucha MJ, Madden MC, Pape G, et al. Effects of cyclooxygenase inhibition on ozone-induced respiratory inflammation and lung function changes. Eur $J \mathrm{Appl}$ Physiol 1996; 73: 17-27.

32. Ogilvy CS, DuBois AB, Douglas JS. Effects of ascorbic acid and indomethacin on the airways of healthy male subjects with and without induced bronchoconstriction. $J$ Allergy Clin Immunol 1981; 67: 363-369.

33. Mohsenin V, DuBois AB, Douglas JS. Effect of ascorbic acid on response to methacholine challenge in asthmatic subjects. Am Rev Respir Dis 1983; 127: 143-147.

34. Devlin RB, McDonnell WF, Becker S, et al. Timedependent changes of inflammatory mediators in the lungs of humans exposed to $0.4 \mathrm{ppm}$ ozone for $2 \mathrm{hr}$ : a comparison of mediators found in bronchoalveolar lavage fluid 1 and $18 \mathrm{hr}$ after exposure. Toxicol Appl Pharmacol 1996; 138: 176-185.

35. Koren HS, Devlin RB, Becker S, Perez R, McDonnell WF. Time-dependent changes of markers associated with inflammation in the lungs of humans exposed to ambient levels of ozone. Toxicol Pathol 1991; 19: 406-411.

36. Schelegle ES, Siefkin AD, McDonald RJ. Time course of ozone-induced neutrophilia in normal humans. Am Rev Respir Dis 1991; 143: 1353-1358.

37. Menzel DB. Antioxidant vitamins and prevention of lung disease. Ann N Y Acad Sci 1992; 669: 141-155.

38. Chow JC. Measurement methods to determine compliance with ambient air quality standards for suspended particles. J Air Waste Manage Assoc 1995; 45: 320-382. 